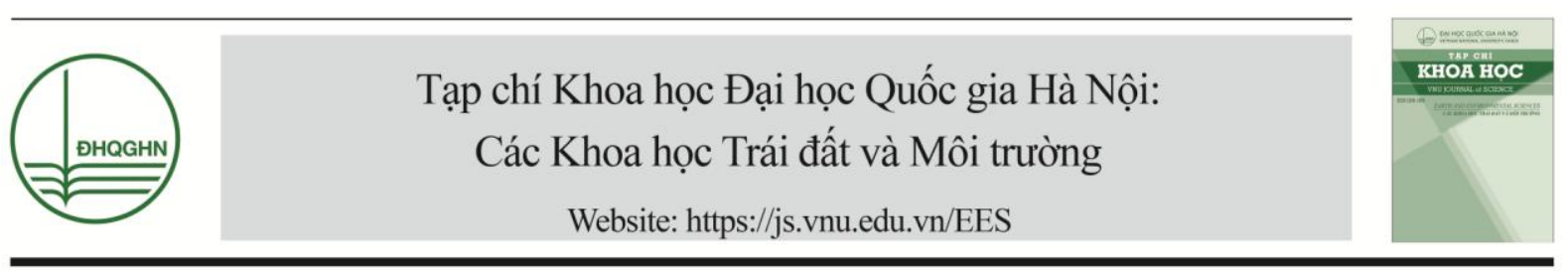

\title{
Chất lượng nước biển ven bờ từ dữ liệu các trạm quan trắc môi trường phía Nam Việt Nam (2013 - 2017)
}

\author{
Phạm Hữu Tâm*
}

Viện Hải duong học - Viện Hàn lâm Khoa học và Công nghệ Việt Nam, Số 01 Cầu Đá, Nha Trang, Khánh Hòa, Việt Nam

Nhận ngày 24 tháng 4 năm 2018

Chỉnh sửa ngày 30 tháng 5 năm 2018; Chấp nhận đăng ngày 30 tháng 5 năm 2018

\begin{abstract}
Tóm tắt: Hệ thống các trạm quan trắc và phân tích môi trường biển phía Nam Việt Nam được thiết lập từ năm 1996 và hoạt động liên tục cho đến nay, trong đó, có ba trạm Nha Trang, Vũng Tàu và Rạch Giá là những trạm được quan trắc liên tục theo tần suất 2 lần/năm. Các thông số môi trường quan trắc trong nước biển ven bờ bao gồm: thông số cơ bản ( $\mathrm{pH}, \mathrm{DO}$, độc đục, TSS), muối dinh dưỡng (ammonia, nitrite, nitrate, phosphate), kim loại nặng $(\mathrm{Zn}, \mathrm{Cu}, \mathrm{Pb}, \mathrm{As}, \mathrm{Cd}, \mathrm{Hg})$ và dầu mỡ khoáng. Các thông số quan trắc trên trong giai đoạn 2013-2017 đã được thu thập, phân tích và đánh giá. Kết quả cho thấy nước biển ven bờ phía Nam Việt Nam nhìn chung còn tương đối tốt về mặt sinh thái, mặc dù hàm lượng các thông số đo đạc có biến đổi theo mùa, pha triều và vùng miền. Tuy nhiên, một vài thông số môi trường như độ đục, tổng chất rắn lơ lửng (TSS), các muối dinh dưỡng tại trạm Vũng Tàu và Rạch Giá vượt giá trị giới hạn (GTGH) được quy định trong các Quy chuấn của Việt Nam (QCVN 10-MT:2015/BTNMT), Úc và ASEAN về chất lượng nước biển ven bờ áp dụng cho nuôi trồng thủy sản và bảo tồn thủy sinh. Phân tích dữ liệu cũng cho thấy có xu thế tăng theo thời gian của giá trị độ đục, TSS và tổng dầu mỡ khoáng. Kểt quả cũng đã phản ảnh được các đặc điểm môi trường từng khu vực quan trắc cũng như tác động của một số hoạt động kinh tế - xã hội đến chất lượng môi trường biển ven bờ phía Nam Việt Nam.
\end{abstract}

Tư khóa: Chất lượng nước biển, quan trắc môi trường, thông số môi trường, Nam Việt Nam.

\section{Mở đầu}

Tuy số lượng điểm quan trắc và tần suất đo chưa đáp ứng được nhu cầu, nhưng các số liệu thu thập được tại ba trạm quan trắc Nha Trang, Vũng Tàu và Rạch Giá là chuỗi số liệu đo đạc

\footnotetext{
*ĐT.: 84-913463972.

Email: tamphamhuu@gmail.com

https://doi.org/10.25073/2588-1094/vnuees.4250
}

chính thống, đáng tin cậy và có hệ thống nhất đối với việc nghiên cứu và đánh giá cũng như theo dõi diễn biến chất lượng môi trường nước biển ven bờ phía Nam Việt Nam cho đến nay.

Kết quả quan trắc tại các trạm này đều được công bố trong báo cáo tổng kết hàng năm phản ảnh hiện trạng môi trường vùng biển phía Nam. Bên cạnh đó, các kết quả quan trắc $\mathrm{c}$ ũng đã được công bố Võ Văn Lành , 1999 [1]; Lã Văn Bài, 2003, 2007, 2009 [2-4]; Phạm Hữu Tâm 
2013, 2015, 2017 [5-8] và Lê Thị Vinh , 2015 $[9,10]$. Tuy nhiên, những nghiên cứu nêu trên chỉ tập trung thống kê và mô tả số liệu quan trắc cũng như sơ bộ đánh giá chất lượng môi trường của từng trạm quan trắc riêng lẻ, chưa tập hợp được số liệu quan trắc của nhiều năm liên tiếp nhẳm đánh giá hiện trạng và xu thế biến động chất lượng môi trường nước biển ven bờ tại ba trạm quan trắc nói riêng và vùng biển ven bờ phía Nam Việt Nam nói chung.

Vì vậy, bài báo này tập trung thu thập, xử lý chuỗi số liệu về các thông số cơ bản, các muối dinh dưỡng, dầu mỡ khoáng và kim loại nặng trong nước biển ven bờ được quan trắc liên tục trong giai đoạn 2013-2017 tại ba trạm quan trắc nhằm đánh giá cũng như xem xét diễn biến chất lượng môi trường nước biển ven bờ tại ba trạm quan trắc thuộc vùng biển phía Nam.

\section{Tài liệu và phương pháp nghiên cứu}

\subsection{Thông tin về trạm quan trắc}

Trạm Nha Trang có tọa độ là $12^{\circ} 12^{\prime} 45^{\prime \prime}$ vĩ độ Bắc, $109^{\circ} 13$ '12” kinh độ Đông. Vị trí trạm nằm gần cảng Nha Trang, cảng hàng hóa, cảng dầu, cảng quân sự, chịu ảnh hưởng của nước Sông Cái và sông Cửa Bé với độ sâu xấp xỉ 20m (Hình 1). Trạm Vũng Tàu có tọa độ là $10^{\circ} 23$ '27” vĩ độ Bắc, $107^{\circ} 01^{\prime} 05^{\prime}$ " kinh độ Đông. Vị trí trạm nằm giữa vịnh Vũng Tàu, trước các cửa sông thuộc hệ thống sông Sài Gòn - Đồng Nai như Ngã Bảy, Gò Gia, Thị Vải, Chà Vá, Dinh, cạnh trạm đèn quan sát phao luồng (Nhà Trắng), ở độ sâu gần $10 \mathrm{~m}$. Trạm nằm ở giữa vịnh, một bên là thị trấn Cần Thạnh, Cần Giờ, thành phố Hồ Chí Minh, một bên là phường Bến Đình, thành phố Vũng Tàu. Toàn bộ khu vực có các cửa sông, rạch là rừng ngập mặn. Có thể nói khu vực này đang chịu sức ép môi trường ngày càng tăng không những do các hoạt động kinh tế dọc các sông Thị Vải, Đồng Nai, Sài Gòn như các cảng thương mại, các khu chế xuất, khu công nghiệp mà còn từ các hoạt động kinh tế khác trong nội địa của các tỉnh Bình Dương, Đồng Nai, Bà Rịa - Vũng Tàu. Trạm Rạch Giá có tọa độ là $09^{\circ} 58^{\prime} 24$ ' vĩ độ Bắc, $105^{\circ} 04^{\prime} 07^{\prime \prime}$ kinh độ Đông. Vị trí lấy mẫu nằm ở độ sâu $2,5-3 \mathrm{~m}$ về phía tây nam của thành phố Rạch Giá. Đây là một vịnh rất nông và bằng phẳng, trao đổi nước với vùng biển bên ngoài khó khăn nên nước từ sông Cửa Lớn hầu như chi phối chất lượng nước trong vịnh. Sông Cửa Lớn là con sông lớn chảy từ đồng bằng sông Cửu Long về phía tây, chảy qua nhiều thị trấn, khu dân cư, đồng ruộng trước khi đổ vào vịnh, nước vịnh có độ mặn thấp.

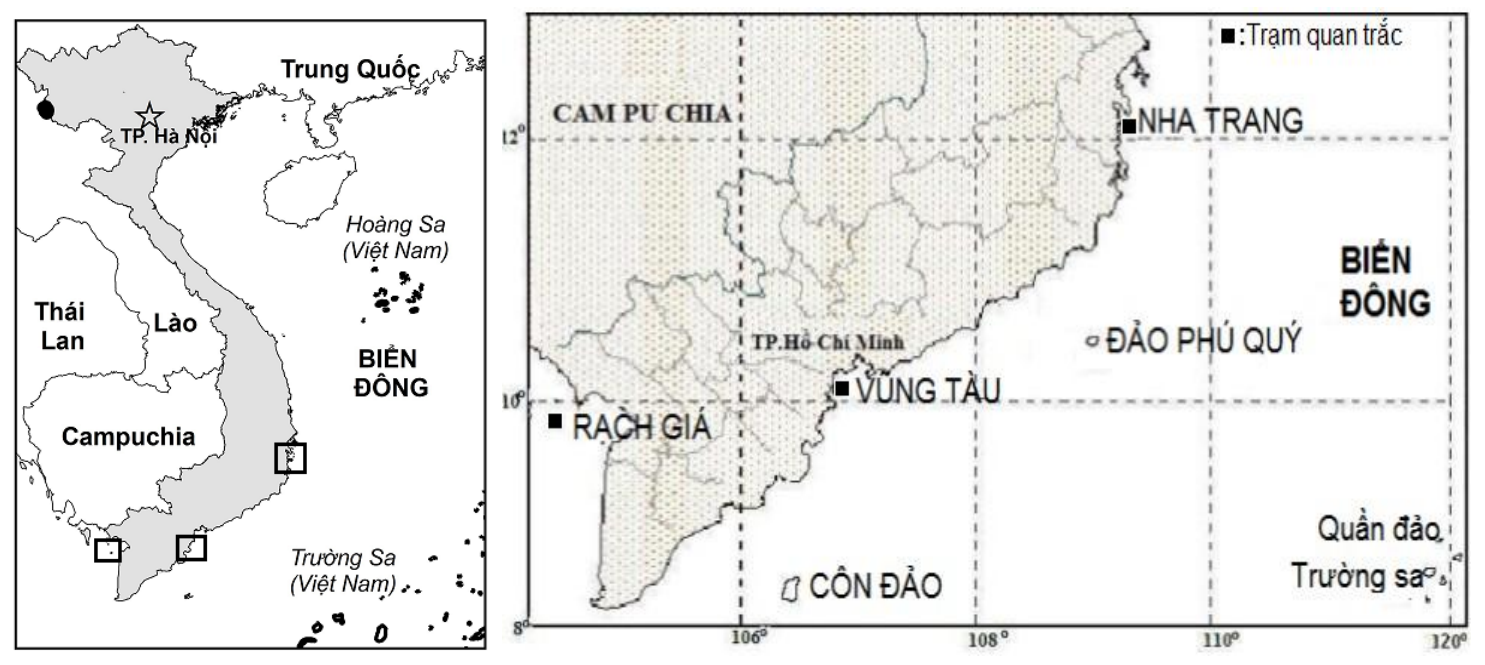

Hình 1. Vị trí ba trạm quan trắc biển ven bờ Nam Việt Nam. 


\subsection{Cơ sở tài liệu}

Cơ sở tài liệu chính là nguồn số liệu lịch sử được thu thập, từ ba trạm Quan trắc và Phân tích môi trường biển phía Nam trong giai đoạn 2013 - 2017.

Tại các trạm quan trắc này, mẫu nước biển ven bờ được thu định kỳ 2 lần/năm (mùa khô và mùa mưa). Mẫu được thu ở hai tầng (mặt và đáy) vào thời điểm chân triều và đỉnh triều. Riêng mẫu kim loại nặng chỉ thu vào thời điểm chân triều, mẫu dầu mỡ khoáng chỉ thu ở tầng mặt, đối với trạm có độ sâu <3m (trạm Rạch Giá) chỉ thu ở tầng mặt. Có tổng cộng 100 mẫu nước biển được thu và phân tích trong giai đoạn 2013 - 2017 tại ba trạm quan trắc nói trên.

Các thông số cơ bản (pH, DO, độc đục, TSS), các muối dinh dưỡng (ammonia, nitrite, nitrate, phosphate), các kim loại nặng ( $\mathrm{Zn}, \mathrm{Cu}$, $\mathrm{Pb}, \mathrm{As}, \mathrm{Cd}, \mathrm{Hg}$ ) và tổng dầu mõ̃ khoáng được lựa chọn để nghiên cứu.

Các mẫu nước biển được xử lý, bảo quản và phân tích theo các phương pháp hiện hành nêu trong Standard Methods for Examination of Water and Wastewater (APHA, 2012) [11]. pH, độ đục đo bằng máy tại hiện trường. $\mathrm{DO}$ sử dụng phương pháp Winkler. TSS phân tích bằng phương pháp trọng lượng. Phosphate được phân tích bằng phương pháp xanh molybden. Nitrite được phân tích phương pháp trắc quang phức màu hồng của nitrite với $\alpha$-naphthylamine và acid sulfanilic. Nitrate được khử thành nitrite qua cột khử $\mathrm{Cd}$ mạ đồng và phân tích theo cùng phương pháp. Ammonia được phân tích bằng phương pháp xanh indophenol. Dầu mỡ khoáng được phân tích theo phương pháp trọng lượng. Các kim loại nặng, trước tiên được xử lý bằng hỗn hợp dung dịch acid đậm đặc $\left(\mathrm{HNO}_{3}-\right.$ $\mathrm{H}_{2} \mathrm{SO}_{4}$ ), sau đó đem phân tích trên máy quang phổ phát xạ ICP-MS.

Chất lượng nước biển được đánh giá dựa trên Quy chuẩn Kỹ thuật Quốc gia về chất lượng nước biển ven bờ (cả ba trạm quan trắc nói trên thuộc vùng biển ven bờ - nằm cách bờ trong phạm vi $5,5 \mathrm{~km}$ ) - áp dụng cho vùng nuôi trồng thủy sản bảo tồn thủy sinh (QCVN 10-
MT:2015/BTNMT). Các thông số như độ đục, nitrite, nitrate không quy định trong QCVN 10MT:2015/BTNMT thì sử dụng Tiêu chuẩn chất lượng nước thủy sản của Australia và các nước ASEAN [12-14]. Các hình ảnh đồ thị trong bài báo được tạo bằng phần mềm Microsoft Excel.

\section{Kết quả nghiên cứu và thảo luận}

\subsection{Chất luợng nước biển ven bò giai đoạn $2013-2017$}

Kết quả xử lý dữ liệu được trình bày trong các bảng từ Bảng 1 đến Bảng 6 .

\section{Các thông số co bản}

Giá trị $\mathrm{pH}$ và hàm lượng $\mathrm{DO}$ dao động trong khoảng tương ứng là $7,01-8,37$ và 2,92 $6,88 \mathrm{mg} / \mathrm{l}$, giá trị thấp thường xuất hiện ở trạm Rạch Giá và giá trị cao xuất hiện tại trạm Nha Trang. Biên độ dao động của độ đục, TSS khá rộng với các giá trị tương ứng là 1,0 - $470 \mathrm{NTU}$ và $0,85-368 \mathrm{mg} / \mathrm{l}$. Giá trị độ đục, TSS thấp thường xuất hiện ở trạm Nha Trang và tại trạm Rạch Giá.

Dựa theo QCVN 10-MT:2015/BTNMT và tiêu chuẩn của Australia, ASEAN về chất lượng nước biển ven bờ, áp dụng cho vùng nuôi trồng thủy sản, bảo tồn thủy sinh cho thấy tại trạm Nha Trang trong suốt quá trình quan trắc các giá trị của thông số cơ bản đều nằm trong GTGH. Tuy nhiên, có sự thiếu hụt DO tại các trạm Vũng Tàu và Rạch Giá, đặc biệt là trạm Rạch Giá với tần xuất $\mathrm{DO}<5 \mathrm{mg} / \mathrm{l}$ xuất hiện khá thường xuyên. Giá trị độ đục và hàm lượng TSS tại hai trạm Vũng Tàu và Rạch Giá khá cao và thường xuyên vượt GTGH.

\section{Các muối dinh duõ̃ng và tổng dầu mõ khoáng}

Hàm lượng của các muối dinh dưỡng tại hai trạm Vũng Tàu và Rạch giá có biên độ dao động khá rộng, trong khi đó tại trạm Nha Trang có biên độ dao động hẹp hơn. Biên độ dao động của các muối phosphate, ammonia, nitrite, nitrate lần lượt là 2 - $63 \mu \mathrm{g} / \mathrm{l} ; 0-186 \mu \mathrm{g} / \mathrm{l} ; 0$ $330 \mu \mathrm{g} / \mathrm{l} ; 26-2470 \mu \mathrm{g} / \mathrm{l}$. Hàm lượng cao của 
các muối dinh dưỡng thường xuất hiện tại các trạm Vũng Tàu và Rạch Giá, trong lúc đó hàm lượng thấp của chúng thường ghi nhận ở trạm Nha Trang. Pham vi dao động của tổng dầu mỡ tại ba trạm quan trắc miền Nam tương đối hẹp (302 - $685 \mu \mathrm{g} / \mathrm{l})$ và ít có sự khác biệt giữa các trạm quan trắc.

Dựa theo QCVN 10-MT:2015/BTNMT và tiêu chuẩn các nước ASEAN về chất lượng nước biển ven bờ, áp dụng cho vùng nuôi trồng thủy sản, bảo tồn thủy sinh thì hàm lượng của các muối dinh dưỡng tại trạm Nha Trang trong suốt quá trình quan trắc thường có giá trị thấp hơn nhiều so với GTGH. Tuy nhiên, cũng như các thông số cơ bản, hàm lượng muối dinh dưỡng nitrate tại trạm Vũng Tàu và Rạch Giá thường có giá trị rất cao và luôn luôn vượt GTGH, các giá trị hàm lượng cao thường xuất hiện ở pha chân triều. Giá trị tổng dầu mỡ, các muối nitrite, ammonia, phosphate nhìn chung ở mức thấp hoặc trung bình, phần lớn đều thấp hơn GTGH, chỉ một vài giá trị vượt GTGH.

Bảng 1. Giá trị thống kê các thông số cơ bản, các muối dinh dưỡng trong nước tại trạm quan trắc Nha Trang giai đoạn 2013 - 2017

\begin{tabular}{|c|c|c|c|c|c|c|c|c|c|}
\hline Năm & $\begin{array}{l}\text { Giá } \\
\text { trị }\end{array}$ & $\mathrm{pH}$ & $\begin{array}{l}\text { DO } \\
(\mathrm{mg} / \mathrm{l})\end{array}$ & $\begin{array}{l}\text { Độ đục } \\
\text { (NTU) }\end{array}$ & $\begin{array}{l}\text { TSS } \\
(\mathrm{mg} / \mathrm{l})\end{array}$ & $\begin{array}{l}\mathrm{PO}_{4}-\mathrm{P} \\
(\mu \mathrm{g} / \mathrm{l})\end{array}$ & $\begin{array}{l}\mathrm{NH}_{3,4}-\mathrm{N} \\
(\mu \mathrm{g} / \mathrm{l})\end{array}$ & $\begin{array}{l}\mathrm{NO}_{2}-\mathrm{N} \\
(\mu \mathrm{g} / \mathrm{l})\end{array}$ & $\begin{array}{l}\mathrm{NO}_{3}-\mathrm{N} \\
(\mu \mathrm{g} / \mathrm{l})\end{array}$ \\
\hline \multirow{5}{*}{2013} & TB $(n=8)$ & 8,09 & 6,76 & 10,68 & 4,76 & 11,63 & 21,40 & 2,56 & 30 \\
\hline & $\mathrm{BN}$ & 7,87 & 6,53 & 2,50 & 1,80 & 8,70 & 9,20 & - & 26 \\
\hline & $\mathrm{LN}$ & 8,37 & 6,96 & 18,90 & 17,70 & 16,80 & 30,40 & 7,00 & 31 \\
\hline & Độ lệch chuẩn & 0,17 & 0,14 & 15,60 & 5,34 & 2,76 & 7,64 & 2,95 & 1,75 \\
\hline & TB $(n=8)$ & 8,12 & 6,58 & 8,63 & 4,26 & 7,50 & 4,25 & 0,31 & 34 \\
\hline \multirow{2}{*}{2014} & $\mathrm{BN}$ & 7,82 & 6,16 & 5,00 & 1,90 & 6,50 & - & - & 34 \\
\hline & $\mathrm{LN}$ & 8,30 & 6,84 & 19,00 & 5,90 & 9,40 & 13,40 & 2,50 & 36 \\
\hline \multirow{6}{*}{2015} & Độ lệch chuẩn & 0,18 & 0,20 & 5,13 & 1,34 & 1,09 & 5,50 & 0,88 & 0,83 \\
\hline & TB $(n=8)$ & 8,23 & 6,32 & 3,71 & 2,23 & 11,60 & 15,71 & 1,76 & 33 \\
\hline & $\mathrm{BN}$ & 8,00 & 5,99 & 1,00 & 1,00 & 6,80 & 7,50 & - & 30 \\
\hline & $\mathrm{LN}$ & 8,41 & 6,58 & 7,40 & 4,03 & 16,20 & 32,00 & 6,20 & 34 \\
\hline & Độ lệch chuẩn & 0,16 & 0,19 & 2,88 & 1,14 & 3,85 & 9,41 & 2,06 & 1,36 \\
\hline & TB $(n=8)$ & 8,31 & 6,55 & 11,60 & 1,57 & 14,99 & 13,05 & 2,01 & 31 \\
\hline \multirow{2}{*}{2016} & $\mathrm{BN}$ & 8,21 & 6,20 & 1,90 & 0,85 & 11,30 & - & - & 28 \\
\hline & $\mathrm{LN}$ & 8,36 & 6,88 & 13,00 & 2,20 & 19,10 & 23,00 & 3,50 & 34 \\
\hline \multirow{5}{*}{2017} & Độ lệch chuẩn & 0,05 & 0,26 & 14,00 & 0,46 & 2,72 & 9,04 & 1,38 & 2,28 \\
\hline & $\mathrm{TB}(\mathrm{n}=8)$ & 8,11 & 6,22 & 3,94 & 3,54 & 7,64 & 21,15 & 5,40 & 32 \\
\hline & $\mathrm{BN}$ & 8,01 & 5,41 & 1,90 & 0,87 & 2,00 & 1,10 & 1,20 & 30 \\
\hline & $\mathrm{LN}$ & 8,15 & 6,70 & 6,60 & 8,33 & 14,80 & 57,30 & 8,30 & 33 \\
\hline & Độ lệch chuẩn & 0,04 & 0,54 & 1,79 & 2,90 & 4,57 & 17,42 & 2,89 & 0,93 \\
\hline GTGH & & $\begin{array}{c}6,5- \\
8,5^{*} \\
\end{array}$ & $\geq 5^{*}$ & $0,5-20 * * *$ & $50^{*}$ & $200 *$ & $100 *$ & $55^{* *}$ & $60 * *$ \\
\hline
\end{tabular}

Ghi chú: (*) - QCVN 10-MT:2015/BTNMT;

(**) - Tiêu chuẩn chất lượng nước biển ven bờ của Australia;

(***) - Tiêu chuẩn chất lượng nước biển ven bờ của ASEAN;

TB - trung bình; BN - bé nhất; LN - lớn nhất; n - số mẫu; HC - tổng dầu mỡ khoáng, “--” là nhỏ hơn giới hạn phát hiện của phép phân tích. 
Bảng 2. Giá trị thống kê các thông số cơ bản, các muối dinh dưỡng trong nước tại trạm quan trắc Vũng Tàu giai đoạn 2013 - 2017

\begin{tabular}{|c|c|c|c|c|c|c|c|c|c|}
\hline \multirow{2}{*}{ Năm } & \multirow{2}{*}{ Giá trị } & \multirow{2}{*}{$\mathrm{pH}$} & DO & Độ đục & TSS & $\mathrm{PO}_{4}-\mathrm{P}$ & $\mathrm{NH}_{3,4}-\mathrm{N}$ & $\mathrm{NO}_{2}-\mathrm{N}$ & $\mathrm{NO}_{3}-\mathrm{N}$ \\
\hline & & & $(\mathrm{mg} / \mathrm{l})$ & (NTU) & $(\mathrm{mg} / \mathrm{l})$ & $(\mu \mathrm{g} / \mathrm{l})$ & $(\mu \mathrm{g} / \mathrm{l})$ & $(\mu \mathrm{g} / \mathrm{l})$ & $(\mu \mathrm{g} / \mathrm{l})$ \\
\hline \multirow{5}{*}{2013} & $\mathrm{~TB}(\mathrm{n}=8)$ & 8,03 & 6,11 & 16,39 & 78,36 & 17,94 & 42,93 & 52,63 & 393 \\
\hline & $\mathrm{BN}$ & 7,84 & 5,41 & 4,30 & 29,20 & 13,60 & 6,00 & 22,00 & 182 \\
\hline & $\mathrm{LN}$ & 8,20 & 6,45 & 30,60 & 142,80 & 22,50 & 82,00 & 106,00 & 719 \\
\hline & Độ lệch chuẩn & 0,13 & 0,38 & 9,15 & 45,60 & 3,62 & 27,07 & 29,13 & 211 \\
\hline & $\mathrm{TB}(\mathrm{n}=8)$ & 8,18 & 5,69 & 95,50 & 45,09 & 14,79 & 8,29 & 21,98 & 175 \\
\hline \multirow{4}{*}{2014} & $\mathrm{BN}$ & 7,92 & 4,93 & 28,00 & 6,40 & 7,50 & - & 5,60 & 114 \\
\hline & $\mathrm{LN}$ & 8,33 & 6,16 & 232,00 & 114,60 & 23,00 & 21,00 & 50,20 & 223 \\
\hline & Độ lệch chuẩn & 0,13 & 0,49 & 70,87 & 33,00 & 5,82 & 8,41 & 14,19 & 44 \\
\hline & $\mathrm{TB}(\mathrm{n}=8)$ & 8,11 & 5,51 & 18,61 & 38,27 & 22,19 & 18,80 & 17,76 & 207 \\
\hline \multirow{4}{*}{2015} & $\mathrm{BN}$ & 7,61 & 4,78 & 1,60 & 8,07 & 16,20 & - & 4,70 & 135 \\
\hline & $\mathrm{LN}$ & 8,37 & 6,16 & 47,70 & 149,50 & 29,10 & 34,80 & 67,40 & 300 \\
\hline & Độ lệch chuẩn & 0,34 & 0,56 & 17,01 & 46,15 & 4,70 & 12,65 & 20,71 & 64 \\
\hline & TB $(n=8)$ & 8,12 & 5,82 & 61,33 & 28,64 & 19,20 & 3,55 & 35,90 & 160 \\
\hline \multirow{4}{*}{2016} & $\mathrm{BN}$ & 8,04 & 5,38 & 19,60 & 7,40 & 13,60 & - & 18,00 & 109 \\
\hline & $\mathrm{LN}$ & 8,27 & 6,10 & 162,90 & 93,67 & 24,60 & 11,80 & 51,00 & 213 \\
\hline & Độ lệch chuẩn & 0,08 & 0,25 & 46,41 & 28,16 & 4,23 & 5,22 & 11,84 & 35 \\
\hline & TB $(n=8)$ & 8,05 & 6,21 & 28,28 & 19,05 & 13,47 & 16,10 & 22,53 & 87 \\
\hline \multirow{3}{*}{2017} & $\mathrm{BN}$ & 7,90 & 5,75 & 12,00 & 10,00 & 8,90 & 7,60 & 9,60 & 62 \\
\hline & $\mathrm{LN}$ & 8,18 & 6,62 & 39,40 & 33,80 & 16,50 & 22,20 & 33,00 & 105 \\
\hline & Độ lệch chuẩn & 0,11 & 0,30 & 16,67 & 27,38 & 2,87 & 5,71 & 10,20 & 25 \\
\hline GTGH & & $\begin{array}{c}6,5- \\
8,5^{*}\end{array}$ & $\geq 5^{*}$ & $0,5-20 * * *$ & $50 *$ & $200^{*}$ & $100^{*}$ & $55 * *$ & $60 * *$ \\
\hline
\end{tabular}

Bảng 3. Giá trị thống kê các thông số cơ bản, các muối dinh dưỡng và tổng dầu mỡ khoáng trong nước tại trạm quan trắc Rạch Giá giai đoạn 2013 - 2017

\begin{tabular}{lllllllllll}
\hline \multirow{2}{*}{ Năm } & \multirow{2}{*}{ Giá trị } & $\mathrm{pH}$ & $\mathrm{DO}$ & Độ đục & $\mathrm{TSS}$ & $\mathrm{PO}_{4}-\mathrm{P}$ & $\mathrm{NH}_{3,4}-\mathrm{N}$ & $\mathrm{NO}_{2}-\mathrm{N}$ & $\mathrm{NO}_{3}-\mathrm{N}$ & $\mathrm{HC}$ \\
\cline { 4 - 10 } & & & $(\mathrm{mg} / \mathrm{l})$ & $(\mathrm{NTU}))$ & $(\mathrm{mg} / \mathrm{l})$ & $(\mu \mathrm{g} / \mathrm{l})$ & $(\mu \mathrm{g} / \mathrm{l})$ & $(\mu \mathrm{g} / \mathrm{l})$ & $(\mu \mathrm{g} / \mathrm{l})$ & $(\mu \mathrm{g} / \mathrm{l})$ \\
\hline \multirow{2}{*}{2013} & TB (n=4) & 7,45 & 4,38 & 71,35 & 54,73 & 42,88 & 113,85 & 139,05 & 1303 & 473 \\
& BN & 7,01 & 3,41 & 12,70 & 13,00 & 34,60 & 15,00 & 5,10 & 145 & 420 \\
& LN & 7,82 & 5,27 & 154,50 & 97,70 & 63,00 & 186,00 & 330,00 & 2470 & 505 \\
& Độ lệch chuẩn & 0,34 & 1,01 & 68,55 & 44,30 & 13,50 & 76,06 & 157,73 & 1324 & 37,97 \\
& TB (n=4) & 8,32 & 6,13 & 171,00 & 68,38 & 34,58 & 27,48 & 2,80 & 178 & 352 \\
\multirow{2}{*}{2014} & BN & 8,45 & 3,00 & 87,00 & 39,50 & 30,70 & 21,50 & - & 136 & 302 \\
& LN & 8,59 & 6,82 & 250,00 & 111,20 & 39,40 & 33,20 & 7,70 & 240 & 464 \\
& Độ lệch chuẩn & 0,33 & 5,39 & 81,49 & 33,12 & 3,70 & 4,91 & 3,66 & 47 & 76,40 \\
& TB (n=4) & 7,50 & 3,65 & 48,03 & 76,33 & 47,10 & 56,25 & 2,50 & 406 & 485 \\
& BN & 7,07 & 2,92 & 12,00 & 6,33 & 40,10 & 7,00 & - & 375 & 465 \\
\hline
\end{tabular}




\begin{tabular}{lllllllllll}
\hline \multirow{2}{*}{2016} & LN & 7,91 & 4,53 & 74,90 & 198,33 & 62,00 & 84,00 & 5,50 & 431 & 505 \\
& Độ lệch chuẩn & 0,40 & 0,66 & 26,72 & 90,26 & 10,04 & 34,13 & 2,92 & 23 & 21,97 \\
& TB (n=4) & 8,00 & 6,36 & 177,55 & 142,93 & 36,20 & 94,15 & 11,43 & 248 & 556 \\
& BN & 7,76 & 5,60 & 16,50 & 16,80 & 27,50 & 25,60 & 2,40 & 127 & 436 \\
& LN & 8,12 & 6,30 & 470,10 & 368,00 & 43,90 & 133,00 & 22,50 & 368 & 685 \\
& Độ lệch chuẩn & 0,16 & 1,15 & 210,63 & 165,70 & 7,86 & 50,69 & 8,77 & 127 & 127,23 \\
& TB (n=4) & 7,66 & 5,61 & 106,05 & 64,98 & 13,25 & 16,33 & 26,48 & 283 & 515 \\
& BN & 7,35 & 5,33 & 43,80 & 26,60 & 8,90 & 11,90 & 16,30 & 109 & 435 \\
& LN & 8,02 & 5,96 & 157,40 & 101,40 & 18,70 & 23,60 & 37,00 & 460 & 598 \\
& Độ lệch chuẩn & 0,36 & 0,30 & 46,92 & 31,00 & 4,15 & 5,08 & 11,04 & 199 & 70,13 \\
\hline
\end{tabular}

\section{Các kim loại nặng}

Các dẫn liệu từ các bảng 4,5 và 6 cho thấy phạm vi dao động hàm lượng của các kim loại nặng trong nước biển tại các trạm quan trắc tương đối hẹp. Biên độ dao động của $\mathrm{Zn}, \mathrm{Cu}$, $\mathrm{Pb}, \mathrm{As}, \mathrm{Cd}$ và $\mathrm{Hg}$ lần lượt là $3,4-25,1 \mu \mathrm{g} / \mathrm{l} ; 1,1$ - 9,4 $\mu \mathrm{g} / 1 ; 0,59$ - 6,82 $\mu \mathrm{g} / 1 ; 1,5$ - 5,8 $\mu \mathrm{g} / \mathrm{l} ; 0,02$ $2,7 \mu \mathrm{g} / \mathrm{l}$ và $0,07-0,23 \mu \mathrm{g} / \mathrm{l}$. Hàm lượng các kim loại tại trạm Nha trang khá đồng nhất và có giá trị thấp hơn so với hai trạm kia. Hàm lượng cao của các kim loại nặng thường tập trung ở trạm Rạch Giá.

Theo QCVN 10-MT:2015/BTNMT về chất lượng nước biển ven bờ, áp dụng cho vùng nuôi trồng thủy sản, bảo tồn thủy sinh cho thấy hàm lượng của các kim loại nặng trong nước $(\mathrm{Zn}$, $\mathrm{Cu}, \mathrm{Pb}, \mathrm{As}, \mathrm{Cd}$ và $\mathrm{Hg}$ ) luôn luôn thấp hơn GTGH trong suốt quá trình tiến hành hoạt động quan trắc từ năm 2013 - 2017.

Bảng 4. Giá trị thống kê hàm lượng các kim loại nặng và tổng dầu mỡ khoáng trong nước tại trạm quan trắc Nha Trang giai đoạn 2013 - 2017

\begin{tabular}{lllllllll}
\hline \multirow{2}{*}{ Năm } & \multirow{2}{*}{ Giá trị } & $\mathrm{Zn}$ & $\mathrm{Cu}$ & $\mathrm{Pb}$ & $\mathrm{As}$ & $\mathrm{Cd}$ & $\mathrm{Hg}$ & $\mathrm{HC}$ \\
\cline { 3 - 8 } & $(\mu \mathrm{g} / \mathrm{l})$ & $(\mu \mathrm{g} / \mathrm{l})$ & $(\mu \mathrm{g} / \mathrm{l})$ & $(\mu \mathrm{g} / \mathrm{l})$ & $(\mu \mathrm{g} / \mathrm{l})$ & $(\mu \mathrm{g} / \mathrm{l})$ & $(\mu \mathrm{g} / \mathrm{l})$ \\
\hline \multirow{3}{*}{2013} & TB (n=4) & 10,51 & 1,86 & 1,14 & 1,88 & 0,13 & 0,13 & 483 \\
& BN & 6,53 & 1,10 & 0,59 & 1,60 & 0,07 & 0,10 & 439 \\
& LN & 14,70 & 2,87 & 2,15 & 2,10 & 0,20 & 0,18 & 560 \\
& Độ lệch chuẩn & 3,65 & 0,85 & 0,70 & 0,26 & 0,06 & 0,04 & 55,49 \\
& TB (n=4) & 6,73 & 3,13 & 1,60 & 2,85 & 0,30 & 0,11 & 373 \\
& BN & 5,70 & 2,40 & 1,30 & 2,60 & 0,10 & 0,08 & 335 \\
& LN & 7,90 & 4,70 & 2,10 & 3,30 & 0,60 & 0,13 & 398 \\
& Độ lệch chuẩn & 1,87 & 1,08 & 0,37 & 0,51 & 0,22 & 0,02 & 29,53 \\
& TB (n=4) & 9,23 & 6,33 & 1,65 & 2,53 & 0,36 & 0,12 & 426 \\
& BN & 8,40 & 2,10 & 1,00 & 2,30 & 0,09 & 0,10 & 399 \\
& LN & 10,50 & 8,60 & 2,30 & 3,00 & 1,00 & 0,15 & 465 \\
& Độ lệch chuẩn & 1,37 & 3,62 & 0,60 & 0,31 & 0,37 & 0,02 & 30,50 \\
& TB (n=4) & 6,93 & 4,58 & 2,05 & 3,65 & 0,12 & 0,13 & 426 \\
& BN & 3,40 & 2,90 & 1,10 & 3,00 & 0,10 & 0,09 & 392 \\
& LN & 11,50 & 5,80 & 3,00 & 4,10 & 0,13 & 0,17 & 472 \\
\hline
\end{tabular}




\begin{tabular}{lllllllll}
\hline & Độ lệch chuẩn & 3,46 & 1,40 & 0,92 & 0,64 & 0,11 & 0,03 & 35,65 \\
& TB $(\mathrm{n}=4)$ & 7,00 & 2,75 & 2,28 & 2,68 & 0,18 & 0,13 & 486 \\
& BN & 5,20 & 2,10 & 1,30 & 2,00 & 0,11 & 0,11 & 415 \\
& LN & 9,50 & 3,40 & 3,00 & 3,70 & 0,30 & 0,15 & 524 \\
GTGH & Độ lệch chuẩn & 1,58 & 0,97 & 0,64 & 0,81 & 0,08 & 0,01 & 50,47 \\
& & $500^{*}$ & $200^{*}$ & $50^{*}$ & $20^{*}$ & $5^{*}$ & $1^{*}$ & $500^{*}$
\end{tabular}

Bảng 5. Giá trị thống kê hàm lượng của các kim loại nặng và tổng dầu mỡ khoáng trong nước tại trạm quan trắc Vũng Tàu giai đoạn 2013 - 2017

\begin{tabular}{|c|c|c|c|c|c|c|c|c|}
\hline \multirow{2}{*}{ Năm } & \multirow{2}{*}{ Giá trị } & $\mathrm{Zn}$ & $\mathrm{Cu}$ & $\mathrm{Pb}$ & As & $\mathrm{Cd}$ & $\mathrm{Hg}$ & $\mathrm{HC}$ \\
\hline & & $(\mu \mathrm{g} / \mathrm{l})$ & $(\mu \mathrm{g} / \mathrm{l})$ & $(\mu \mathrm{g} / \mathrm{l})$ & $(\mu \mathrm{g} / \mathrm{l})$ & $(\mu \mathrm{g} / \mathrm{l})$ & $(\mu \mathrm{g} / \mathrm{l})$ & $(\mu \mathrm{g} / \mathrm{l})$ \\
\hline \multirow{5}{*}{2013} & TB $(n=4)$ & 11,87 & 1,96 & 2,85 & 1,95 & 0,06 & 0,17 & 425,5 \\
\hline & $\mathrm{BN}$ & 8,55 & 1,40 & 1,10 & 1,50 & 0,02 & 0,12 & 305,00 \\
\hline & $\mathrm{LN}$ & 16,47 & 2,98 & 4,52 & 2,75 & 0,10 & 0,23 & 565,00 \\
\hline & Độ lệch chuẩn & 3,66 & 0,70 & 1,74 & 0,57 & 0,04 & 0,06 & 107,69 \\
\hline & TB $(n=4)$ & 8,55 & 3,68 & 2,55 & 2,93 & 0,21 & 0,12 & 360,75 \\
\hline \multirow{2}{*}{2014} & $\mathrm{BN}$ & 8,30 & 2,40 & 1,60 & 2,60 & 0,05 & 0,07 & 305,00 \\
\hline & $\mathrm{LN}$ & 8,80 & 5,80 & 3,30 & 3,30 & 0,40 & 0,20 & 464,00 \\
\hline \multirow{6}{*}{2015} & Độ lệch chuẩn & 0,24 & 1,59 & 0,70 & 0,38 & 0,17 & 0,06 & 70,47 \\
\hline & TB $(n=4)$ & 10,05 & 5,95 & 2,08 & 2,33 & 1,02 & 0,11 & 473,50 \\
\hline & $\mathrm{BN}$ & 7,10 & 3,50 & 1,10 & 1,90 & 0,14 & 0,09 & 430,00 \\
\hline & $\mathrm{LN}$ & 12,80 & 9,40 & 3,50 & 2,90 & 2,70 & 0,14 & 560,00 \\
\hline & Độ lệch chuẩn & 2,65 & 2,86 & 1,08 & 0,42 & 1,21 & 0,02 & 60,21 \\
\hline & TB $(n=4)$ & 7,98 & 3,45 & 2,03 & 4,23 & 0,15 & 0,13 & 473,25 \\
\hline \multirow{2}{*}{2016} & $\mathrm{BN}$ & 4,20 & 2,20 & 1,70 & 3,20 & 0,14 & 0,10 & 397,00 \\
\hline & $\mathrm{LN}$ & 10,90 & 4,80 & 2,50 & 5,80 & 0,17 & 0,18 & 638,00 \\
\hline \multirow{5}{*}{2017} & Độ lệch chuẩn & 2,90 & 1,34 & 0,36 & 1,17 & 0,02 & 0,04 & 111,01 \\
\hline & TB $(n=4)$ & 7,20 & 2,85 & 2,60 & 2,75 & 0,07 & 0,18 & 576,33 \\
\hline & $\mathrm{BN}$ & 7,00 & 2,20 & 1,20 & 2,10 & 0,05 & 0,17 & 510,00 \\
\hline & $\mathrm{LN}$ & 7,40 & 3,50 & 4,00 & 3,40 & 0,09 & 0,19 & 684,00 \\
\hline & Độ lệch chuẩn & 0,68 & 0,70 & 1,28 & 0,54 & 0,05 & 0,04 & 106,89 \\
\hline GTGH & & $500 *$ & $200^{*}$ & $50 *$ & $20 *$ & $5^{*}$ & $1 *$ & $500 *$ \\
\hline
\end{tabular}

Bảng 6. Giá trị thống kê hàm lượng của các kim loại nặng trong nước tại trạm quan trắc Rạch Giá giai đoạn 2013 - 2017

\begin{tabular}{llllllll}
\hline \multirow{2}{*}{ Năm } & \multirow{2}{*}{ Giá trị } & $\mathrm{Zn}$ & $\mathrm{Cu}$ & $\mathrm{Pb}$ & $\mathrm{As}$ & $\mathrm{Cd}$ & $\mathrm{Hg}$ \\
\cline { 3 - 8 } & & $(\mu \mathrm{g} / \mathrm{l})$ & $(\mu \mathrm{g} / \mathrm{l})$ & $(\mu \mathrm{g} / \mathrm{l})$ & $(\mu \mathrm{g} / \mathrm{l})$ & $(\mu \mathrm{g} / \mathrm{l})$ & $(\mu \mathrm{g} / \mathrm{l})$ \\
\hline \multirow{3}{*}{2013} & TB $(\mathrm{n}=4)$ & 20,31 & 6,40 & 4,21 & 3,30 & 0,13 & 0,14 \\
& $\mathrm{BN}$ & 15,70 & 5,99 & 1,60 & 2,70 & 0,11 & 0,12 \\
& LN & 24,91 & 6,80 & 6,82 & 3,90 & 0,14 & 0,16 \\
& Độ lệch chuẩn & 6,51 & 0,57 & 3,69 & 0,85 & 0,02 & 0,03 \\
\hline
\end{tabular}




\begin{tabular}{llllllll}
\hline \multirow{3}{*}{2014} & TB $(\mathrm{n}=4)$ & 9,30 & 6,15 & 3,60 & 3,70 & 0,59 & 0,17 \\
& BN & 7,80 & 2,90 & 3,50 & 3,60 & 0,08 & 0,12 \\
& LN & 10,80 & 9,40 & 3,70 & 3,80 & 1,10 & 0,21 \\
& Độ lệch chuẩn & 2,12 & 4,60 & 0,14 & 0,14 & 0,72 & 0,06 \\
& TB $(\mathrm{n}=4)$ & 19,15 & 5,10 & 3,30 & 3,00 & 0,59 & 0,12 \\
& BN & 13,20 & 2,50 & 1,80 & 3,00 & 0,18 & 0,10 \\
& LN & 25,10 & 7,70 & 4,80 & 3,00 & 1,00 & 0,14 \\
& Độ lệch chuẩn & 8,41 & 3,68 & 2,12 & 0,00 & 0,58 & 0,03 \\
& TB (n=4) & 7,85 & 2,60 & 2,00 & 3,35 & 0,23 & 0,12 \\
& BN & 7,80 & 2,20 & 1,20 & 3,20 & 0,20 & 0,11 \\
& LN & 7,90 & 3,00 & 2,80 & 3,50 & 0,25 & 0,12 \\
& Độ lệch chuẩn & 0,07 & 0,57 & 1,13 & 0,21 & 0,04 & 0,01 \\
& TB $(\mathrm{n}=4)$ & 10,20 & 5,75 & 3,25 & 2,20 & 0,15 & 0,13 \\
& BN & 8,70 & 2,10 & 1,80 & 1,50 & 0,07 & 0,12 \\
& LN & 11,70 & 9,40 & 4,70 & 2,90 & 0,22 & 0,14 \\
& ĐTĜ lệch chuẩn & 2,12 & 5,16 & 2,05 & 0,99 & 0,11 & 0,01 \\
& & $500^{*}$ & $200^{*}$ & $50^{*}$ & $20 *$ & $5 *$ & $1 *$ \\
\hline
\end{tabular}

3.2. Biến động theo mùa hàm lương của các thông số môi truờng nước

Dẫn liệu so sánh hàm lượng trung bình của các thông số môi trường trong giai đoạn 20132017 (Hình 2) cho thấy giá trị pH và hàm lượng của các muối dinh dưỡng (ammonia, phosphate), các kim loại nặng $(\mathrm{Zn}, \mathrm{As}, \mathrm{Hg})$ và tổng dầu mỡ khoáng ít có sự khác biệt giữa hai mùa (mùa khô - tháng 4 và mùa mưa - tháng 8 ). Giá trị độ đục, hàm lượng TSS tại hai trạm Nha Trang và Rạch Giá vào mùa mưa thường lớn hơn mùa khô. Ngược lại, giá trị độ đục, hàm lượng muối nitrate tại trạm quan trắc Vũng Tàu và hàm lượng $\mathrm{DO}$, các muối (nitrite, ammonia) tại trạm quan trắc Rạch Giá mùa khô lại lớn hơn mùa mưa. Hàm lượng các kim loại nặng $\mathrm{Cu}, \mathrm{Pb}, \mathrm{Cd}$ tại trạm Rạch Giá và $\mathrm{Cd}$ tại trạm Vũng Tàu vào mùa mưa lớn hơn so với mùa khô. Dẫn liệu từ các Hình 3, 4, 5 cũng cho thấy chất lượng nước tại trạm quan trắc Nha Trang trong cả hai mùa vẫn còn khá tốt, hầu hết hàm lượng các thông số môi trường được quan trắc đều có giá trị thấp hơn GTGH. Có sự ô nhiễm của độ đục, nitrate tại trạm quan trắc Vũng Tàu ở cả hai mùa (giá trị của độ đục và nitrate thường vượt GTGH). Chất lượng nước tại trạm Rạch Giá đang bị suy giảm và mùa mưa thường có chất lượng kém hơn, ở đây có sự thiếu hụt $\mathrm{DO}$ vào mùa mưa. Giá trị của độ đục, TSS, nitrate đều vượt GTGH trong cả 2 mùa (trong đó độ đục, TSS và nitrate lần lượt vượt GTGH 7,3 lần; 2 lần và 12 lần vào mùa mưa). Hàm lượng tổng dầu mỡ khoáng vào mùa mưa tại hai trạm quan trắc Vũng Tàu và Rạch Giá vượt GTGH, tuy nhiên mức độ vượt không đáng kể. Sự tập trung hàm lượng cao của độ đục, TSS cũng như sự gia tăng về hàm lượng của độ đục, TSS, các kim loại nặng $\mathrm{Cu}, \mathrm{Pb}, \mathrm{Cd}$ trong cả hai mùa và đặc biệt có sự thiếu hụt $\mathrm{DO}$ trong mùa mưa tại trạm quan trắc Rạch Giá đã chứng tỏ khu vực quan trắc bị ảnh hưởng bởi các hoạt dân sinh cũng như kinh tế ở vùng vịnh Rạch Giá, điều này phù hợp với những nghiên cứu trước đây [6-8].

Các chất có nguồn gốc đất liền do sông tải ra đã và đang gây ảnh hưởng đến chất lượng nước biển ven bờ, điều này thể hiện ở hàm lượng TSS, độ đục, một số muối dinh dưỡng thường xuyên cao, đặc biệt có sự thiếu hụt ôxy hoà tan, điều này thể hiện rõ ở trạm Rạch Giá. 

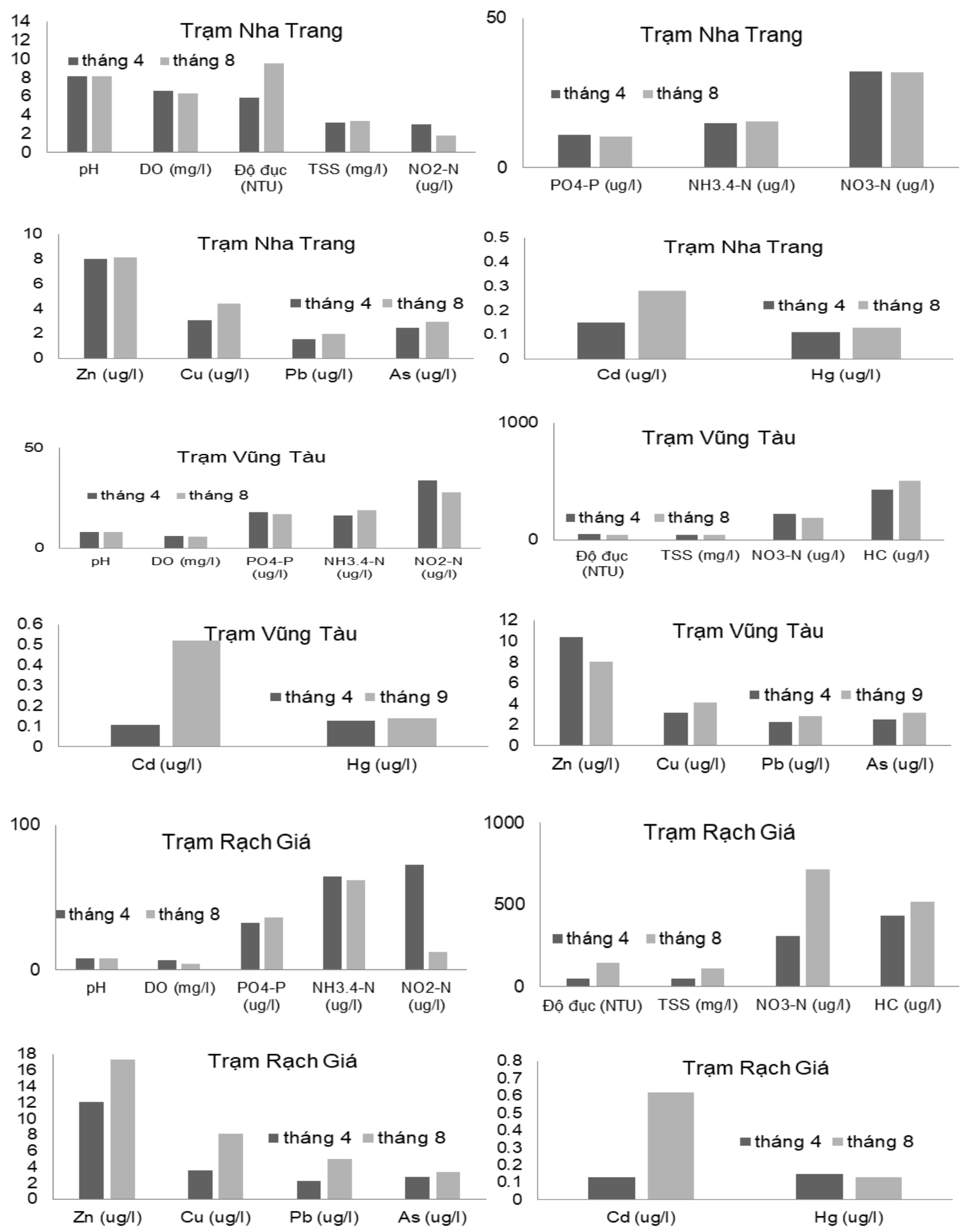

Hình 2. So sánh giá trị trung bình của các thông số môi trường tại các trạm quan trắc theo mùa giai đoạn 2013 - 2017. 
3.3. Diễn biến của các thông số môi trương trong nước

Dựa vào đồ thị minh họa ở các Hình $3,4,5$ cho thấy diễn biến theo thời gian của các thông số môi trường tại ba trạm quan trắc phía Nam Việt Nam trong giai đoạn 2013 - 2017:

Tại trạm Nha Trang: DO và tổng dầu mõ khoáng ít thay đổi theo thời gian. Độ đục, TSS và nitrite có sự gia tăng trong năm 2013 (lúc chân triều), 2015 và 2017 (lúc đỉnh triều). Các
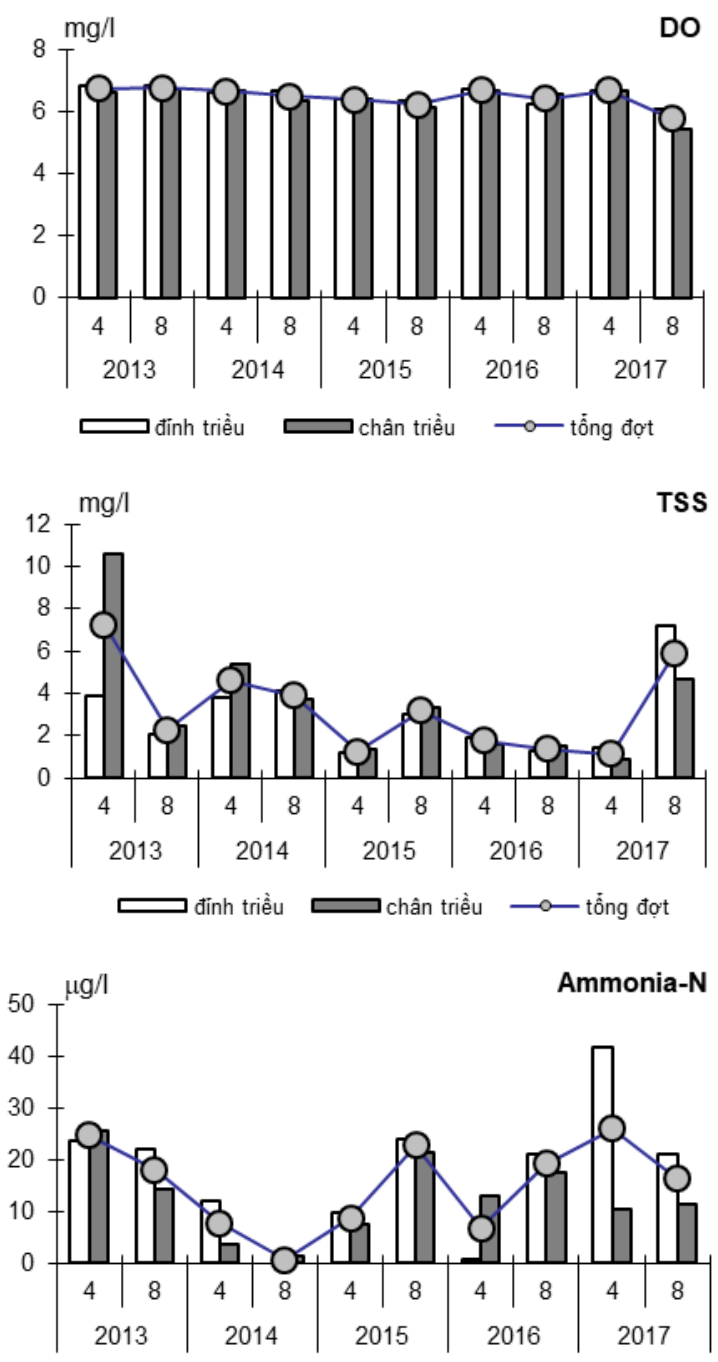

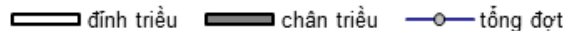

muối phosphate, ammonia giảm từ năm 2013 2014, sau đó tăng lên vào năm 2016 rồi lại giảm trong năm 2017. Các kim loại nặng $(\mathrm{Cu}, \mathrm{Pb})$ lại tăng cao trong năm 2015. Các muối dinh dưỡng (phosphate, nitrite, nitrate) vào lúc chân triều cao hơn so với đỉnh triều, trong khi đó muối ammonia thì có xu hướng ngược lại. Nhìn chung, độ đục và các kim loại $(\mathrm{Pb}$ và $\mathrm{Hg})$ có $\mathrm{xu}$ hướng tăng theo thời gian quan trắc tại trạm này.
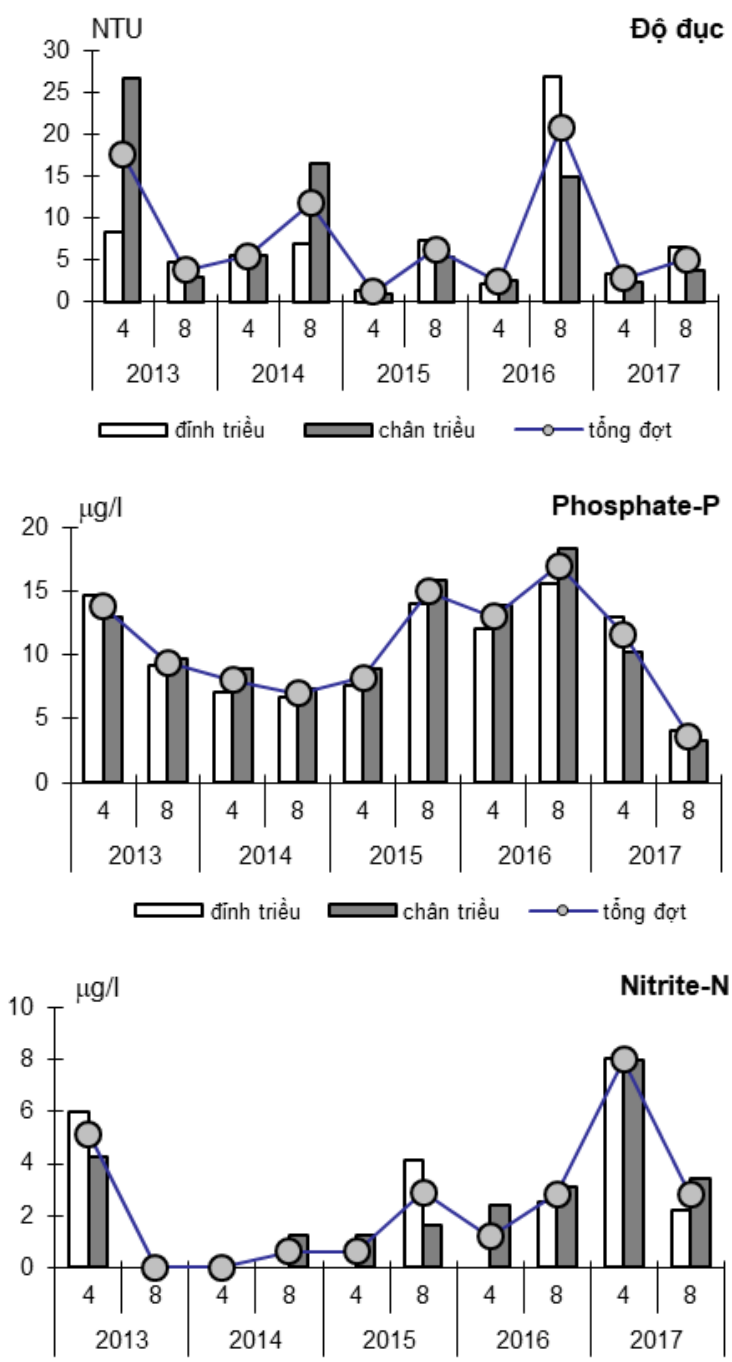

凹 đỉnh triều $\square$ chân triều $\longrightarrow$ - tổng đợt 

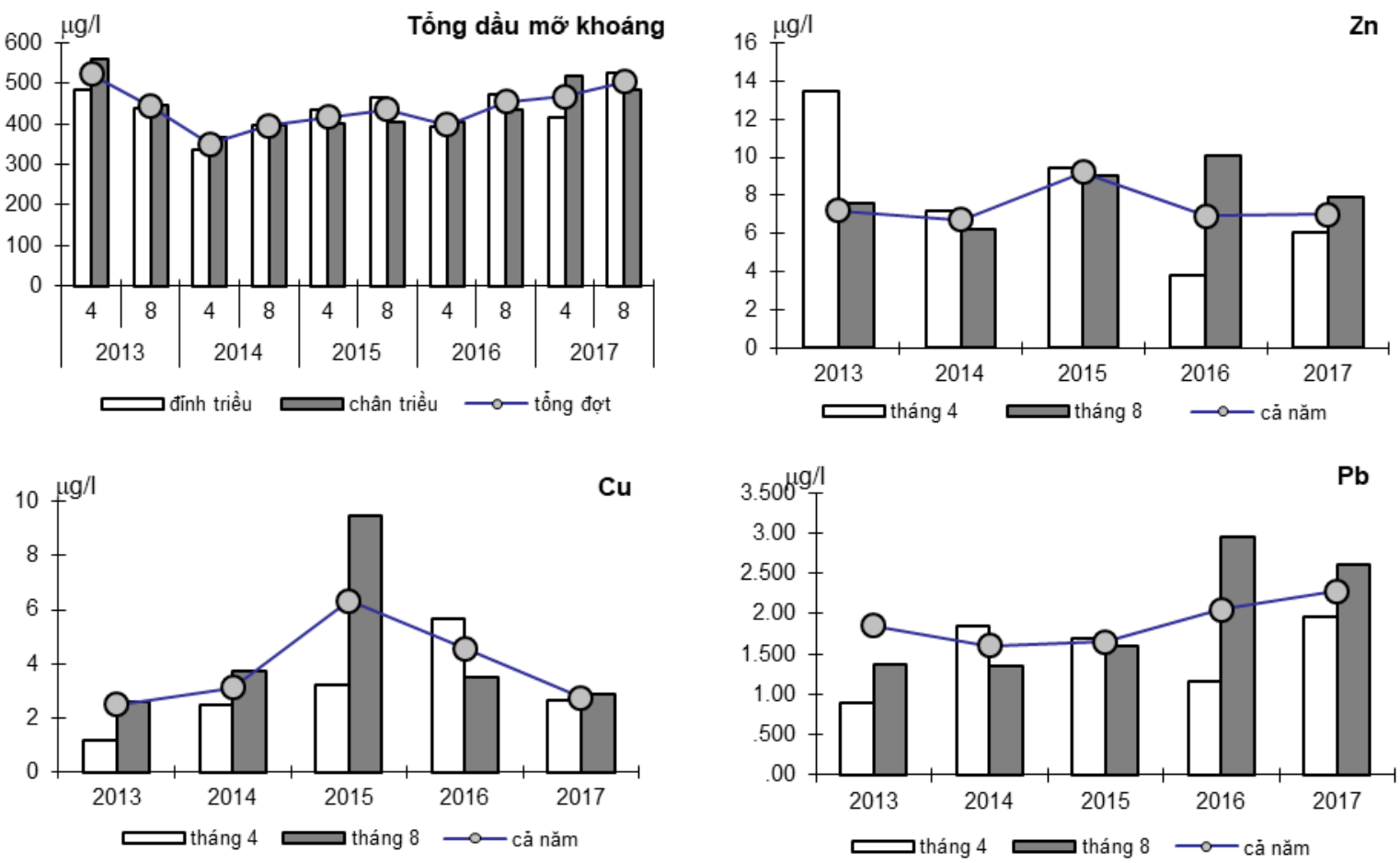

Hình 3. Diễn biến của các thông số môi trường tại trạm quan trắc Nha Trang giai đoạn 2013 - 2017

Tại trạm Vũng Tàu: $\mathrm{pH}$ và $\mathrm{DO}$ biến động nhẹ. TSS và các muối dinh dưỡng (ammonia, nitrite, nitrate) tăng cao trong năm 2013 lúc đỉnh triều, độ đục (lúc chân triều) tăng trong năm 2014 và muối phosphate (lúc chân triều) tăng trong năm 2015. Các kim loại nặng $\mathrm{Zn}, \mathrm{Pb}$, Hg tăng mạnh trong năm 2013, Cu và $\mathrm{Cd}$ tăng trong năm 2015 và As tăng trong năm 2016.
Vào thời điểm chân triều, độ đục, TSS và các muối phosphate, nitrite, nitrate thường cao hơn so với đỉnh triều, trong khi đó $\mathrm{pH}, \mathrm{DO}$ và ammonia có xu hướng ngược lại. Kết quả cho thấy, độ đục, tổng dầu mỡ khoáng, các kim loại nặng As, Hg có xu hướng tăng, nhưng nitrate và Zn lại giảm theo thời gian quan trắc.
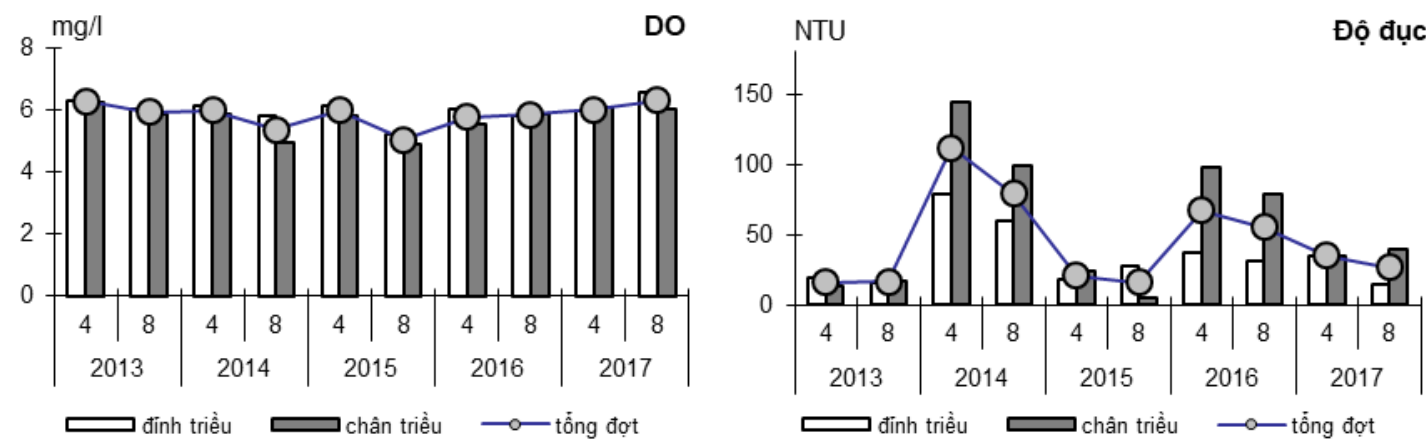

đỉnh triều

chân triều $\quad$ —- tổng đợt 

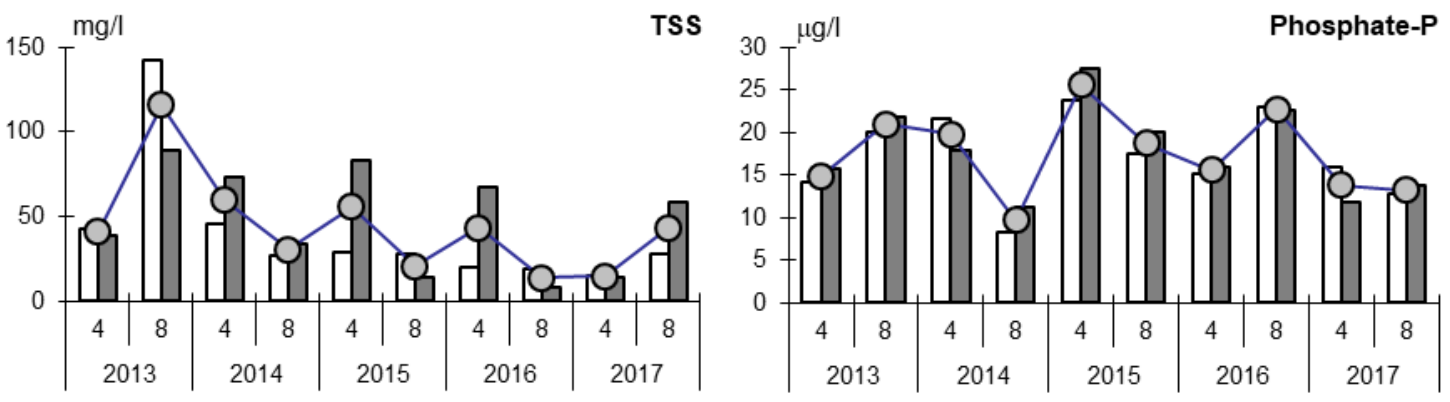

đỉnh triều

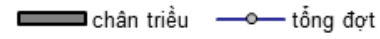

đỉnh triều
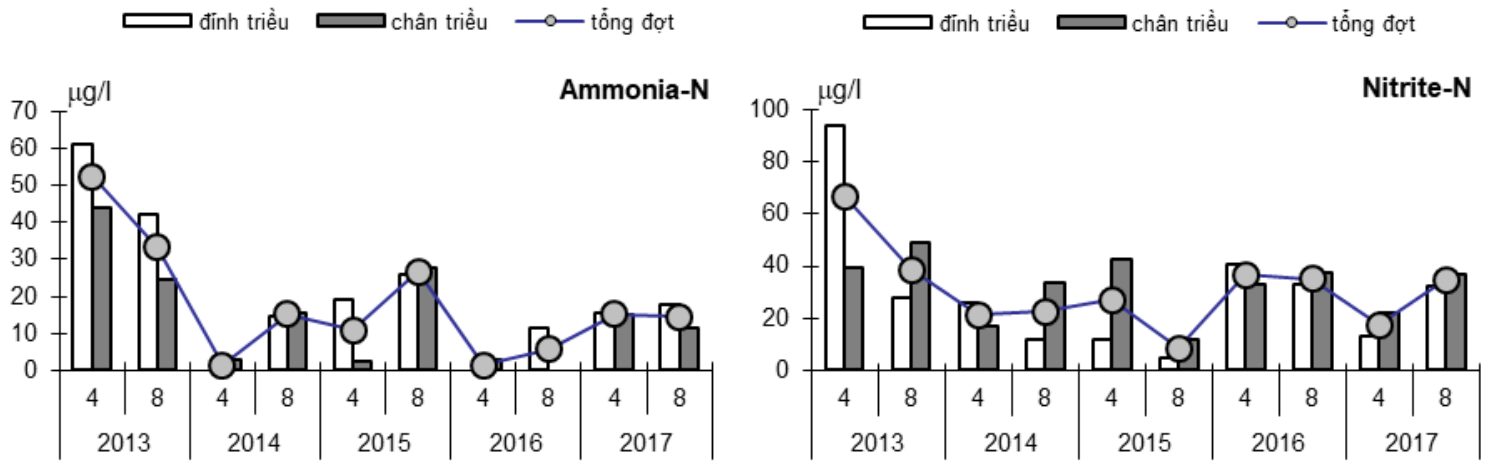

凹 đinh triều $\rightleftharpoons$ chân triều $\longrightarrow$ - tổng đợt

凹 đinh triều $\rightleftharpoons$ chân triều $\longrightarrow$ - tổng đợt
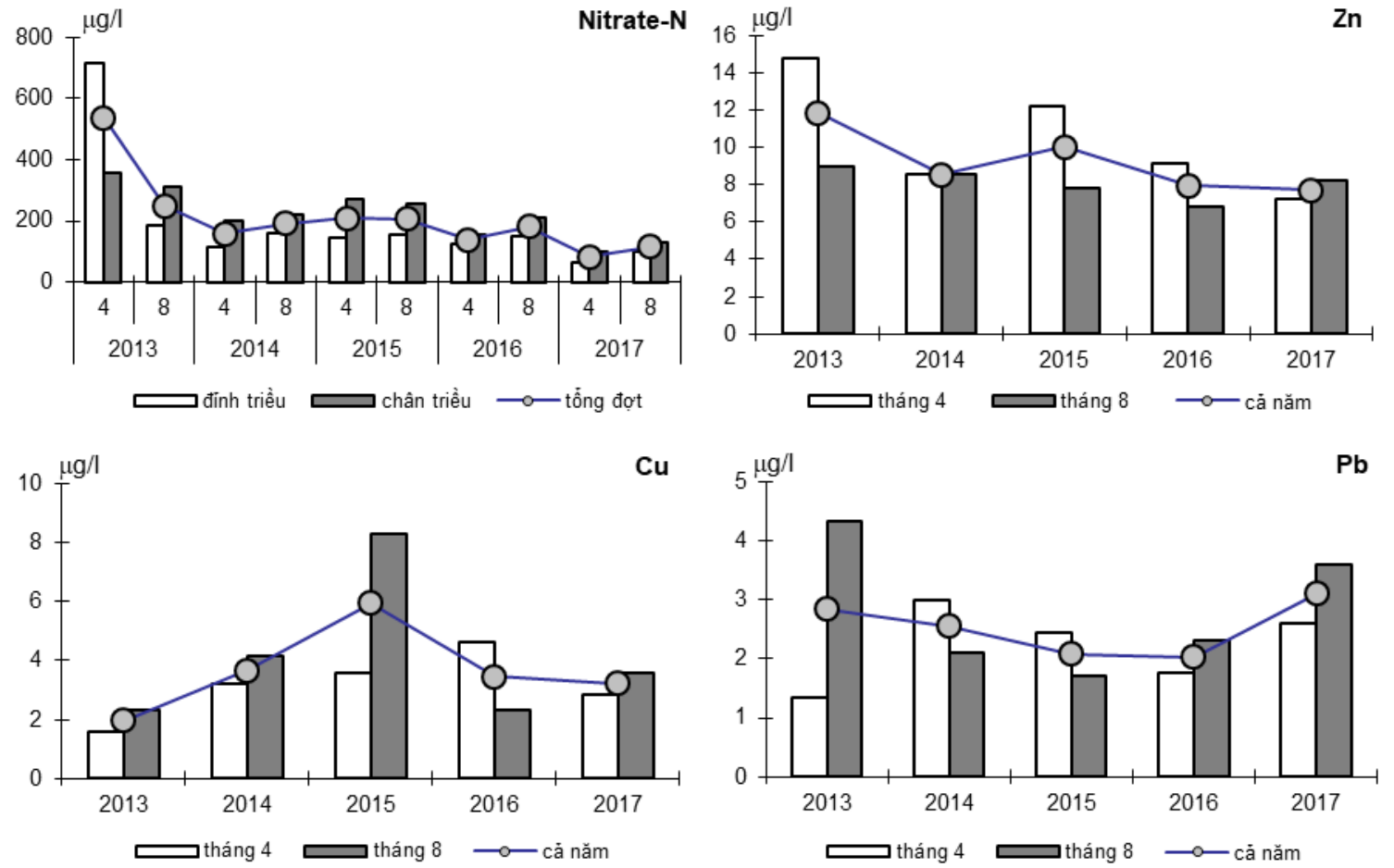

Hình 4. Diễn biến của các thông số môi trường trong nước biển tại trạm quan trắc Vũng Tàu giai đoạn 2013 - 2017 
Tại trạm Rạch Giá: pH ít biến động theo thời gian quan trắc, DO giảm trong năm 2015 . Độ đục và TSS (lúc chân triều) tăng mạnh trong năm 2016, các muối (phosphate, ammonia, nitrite) tăng cao trong năm 2013 vào lúc chân triều. Các kim loại nặng $\mathrm{Zn}, \mathrm{Cu}, \mathrm{Pb}, \mathrm{Cd}$ tăng cao trong các năm 2014 và 2015 . Độ đục, TSS, $\mathrm{DO}$, các muối (phosphate, ammonia, nitrate) và tổng dầu mỡ khoáng vào thời điểm chân triều thường cao hơn so với đỉnh triều.
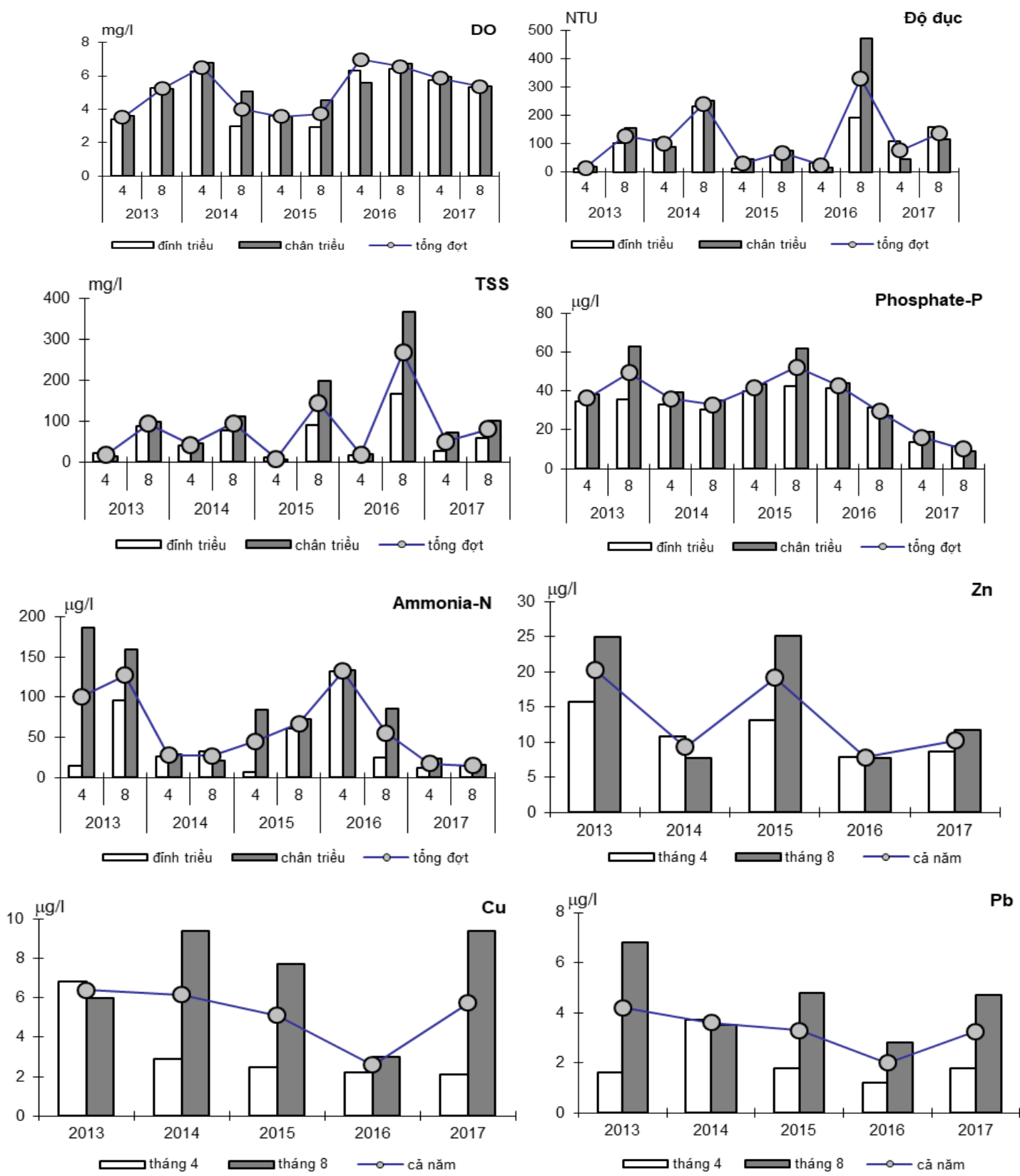

Hình 5. Diễn biến của các thông số môi trường trong nước biển tại trạm quan trắc Rạch Giá giai đoạn 2013 - 2017. 
Nhìn chung, các muối dinh dưỡng (nitrite, nitrate) có xu hướng giảm, trong lúc đó độ đục, TSS và tổng dầu mỡ khoáng thì có xu hướng tăng theo thời gian quan trắc tại trạm này. Như vậy, qua việc xem xét diễn biến hàm lượng của các yếu tố môi trường trong nước biển tại ba trạm quan trắc biển miền Nam cho thấy hàm lượng cao của độ đục, TSS, các muối phosphate, ammonia, nitrite, nitrate thường xuất hiện vào thời điểm chân triều. Có sự suy giảm của các muối nitrite và nitrate, nhưng lại có sự gia tăng của độ đục, TSS, tổng dầu mỡ khoáng theo thời gian tại hai trạm Vũng Tàu và Rạch Giá. Với sự phát triển nhanh chóng của các hoạt động kinh tế vùng bờ như đô thị hóa, du lịch, đánh bắt, nuôi trồng thủy sản, hoạt động hàng hải sẽ gây nên những tác động đến môi trường biển trong tương lai.

\section{Kết luận}

Các kết quả cho thấy, mặc dù hàm lượng các thông số đo đạc có những biến đổi theo mùa, pha triều và theo từng khu vực, một vài thông số môi trường như độ đục, tổng chất rắn lơ lửng (TSS), các muối dinh dưỡng ammonia, nitrite, nitrat tại trạm Vũng Tàu và Rạch Giá vượt GTGH được quy định trong các Quy chuẩn của Việt Nam (QCVN 10MT:2015/BTNMT), Úc và ASEAN về chất lượng nước biển ven bờ áp dụng cho nuôi trồng thủy sản và bảo tồn thủy sinh. Tuy nhiên, nhìn chung chất lượng nước biển ven bờ tại ba trạm quan trắc phía Nam Việt Nam nói riêng và vùng biển ven bờ phía Nam nói chung vẫn còn khá tốt. Bên cạnh đó, việc phân tích dữ liệu môi trường trong giai đoạn 2013-2017 cho thấy có xu thế tăng theo thời gian của giá trị độ đục, TSS và tổng dầu mỡ khoáng.

Các chất có nguồn gốc đất liền do sông tải ra đã và đang gây ảnh hưởng đến chất lượng nước biển ven bờ, điều này thể hiện ở hàm lượng TSS, độ đục, một số muối dinh dưỡng thường xuyên cao, đặc biệt có sự thiếu hụt ôxy hoà tan, điều này thể hiện rõ ở trạm Rạch Giá.

\section{Lời cảm ơn}

Tác giả xin chân thành cảm ơn Trạm Quan trắc và Phân tích môi trường biển miền Nam đã cho phép sử dụng nguồn số liệu.

\section{Tài liệu tham khảo}

[1] Vo Van Lanh, Some estimates on the pollution level of the coastal waters in the South Vietnam, Proceeding of the fourth ASEAN-CANADA Technical Conference on Marine Science, Langkawi, Malaysia, 1999.

[2] Lã Văn Bài , Hiện trạng môi trường biển ven bờ Nam Việt Nam (1996-2002), Tuyển $t$ ập Nghiên cứu Biển XIII, NXB Khoa học và Kỹ thuật, 2002.

[3] Lã Văn Bài, Diễn biến hiện trạng môi trường $b$ iển ven bờ Nam Việt Nam (2002-2006), Kỷ yếu hội thảo Quốc gia "Biển Đông”, NXB KHTN \& CN, 2007.

[4] Lã Văn Bài , Diễn biến các yếu tố ô nhiễm biển ven bờ Việt Nam từ đất liền qua số liệ u 12 năm quan trắc (1996-2007), Tuyển t ập Nghiên cứu Biển XVI, NXB KH \& KT, 2009.

[5] Phạm Hữu Tâm, Diễn biến chất lượng nước tại trạm quan trắc môi trường biển Quốc gia, vịnh Nha Trang, Kỷ yếu Hội nghị Khoa học Toàn quốc về Môi trường và Sinh thái lần $\mathrm{V}$, Hà Nội, 2013.

[6] Phạm Hữu Tâm, Lê Thị Vinh, Dương Trọng Kiểm, Nguyễn Hồng Thu, Phạm Hồng Ngọc, Biến động nồng độ các chất dinh dưỡng trong nước tại trạm quan trắc môi trường biển Nha Trang (19972014), số 2, Tuyển tập NCB XXI, 2015.

[7] Phạm Hữu Tâm, Lê Thị Vinh, Diễn biến chất lương nước tại các trạm Quan Trắc môi trường biển phía Nam, chuyên đề số 1 , Tạp chí Môi trường, 2017.

[8] Phạm Hữu Tâm, Áp dụng chỉ số chất lượng nước để đánh giá chất lượng môi trường tại các trạm quan trắc môi trường biển phía Nam Việt Nam trong giai đoạn 2013-2017 (2011-2015), Tập 32, số 4, Chuyên san các Khoa học trái đất \& Môi trường, Tạp chí Khoa học Đại học Quốc gia Hà Nội, 2017.

[9] Lê Thị Vinh, Dương Trọng Kiểm, Nguyễn Hồng Thu, Phạm Hữu Tâm, Phạm Hồng Ngọc, Hàm lượng các kim loại nặng trong trầm tích tại các trạm quan trắc Nha Trang , Vũng Tàu, Rạch Giá (1998-2014). Tuyển $t$ ập Nghiên cứu Biển XVI , NXB Khoa học và Kỹ thuật, 2015. 
[10] Lê Thị Vinh, Phạm Hữu Tâm, Dương Trọng Kiểm, Nguyễn Hồng Thu, Phạm Hồng Ngọc, Lê Hùng Phú và Võ Trần Tuấn Linh, Hàm lượng các kim loại nặng trong trầm tích tại các trạm quan trắc Nha Trang, Vũng Tàu và Rạch Giá (19982014). Tuyển tập NCB XXI, 2015.

[11] APHA, Standard methods for the examination of water and wastewater. $22^{\text {nd }}$ Edition. American Public Health Association, Washington D.C, 2012.

[12] Bộ Tài nguyên và Môi trường, Quy chuẩn Kỹ thuật Quốc gia về chấ $\mathrm{t}$ lượng môi trường nước biển, QCVN 10-MT: 2015/BTNMT, Hà Nội , 2015.

[13] ANZECC, Australian Water Quality Guidelines for Fresh and Marine Waters. National Water Quality Management Strategy Paper No.4, Australian and NewZealand Environment and Conservation Council, Canberra, 1992.

[14] Australian Government, ASEAN Marine Water Quality Management Guidelines and Monitoring Manual. Asean Marine Water Quality Criteria, 2008.

\title{
Coastal Seawater Quality from Data at South Vietnam Monitoring Stations during 2013 - 2017
}

\author{
Pham Huu Tam \\ Institute of Oceanography, Vietnam Academy of Science \& Technology (VAST), \\ 01 Cau Da, Nha Trang, Khanh Hoa, Vietnam
}

\begin{abstract}
The network of marine environmental monitoring stations in South of Vietnam was established in 1996 and has been operating continuously. Of which, three stations (Nha Trang, Vung Tau and Rach Gia) were stations, which are monitored with the frequency of two times a year. The environmental monitoring parameters in coastal seawater include: Basic parameters ( $\mathrm{pH}$, Dissolved Oxygen, Turbidity, Total Suspended Solids), nutrients (ammonia, nitrite, nitrate, phosphate), heavy metals ( $\mathrm{Zn}, \mathrm{Cu}, \mathrm{Pb}, \mathrm{As}, \mathrm{Cd}, \mathrm{Hg}$ ), Oils and Grease. These monitoring parameters from 2013 to 2017 have been collected, analyzed and assessed. Results in three coastal monitoring stations indicated that southern coastal seawater is still clean, although concentration of the measured parameters vary to seasonal, tide and from site to site. Nevertheless, several parameters such as turbidity, TSS, nutrients in Vung Tau and Rach Gia exceed the standard values of Vietnam National Technical Regulation (QCVN 10-MT:2015/BTNMT), Australia and ASEAN Marine Water Quality Criteria for aquaculture purposes and Aquatic Life Protection.

Data analysis in the last five years also showed that increasing trend over time of turbidity, TSS and oils and grease in Vung Tau and Rach Gia. These results reflect environmental characteristics of each monitoring area, as well as the impact of socio-economic activities on coastal seawater quality in South of Vietnam.
\end{abstract}

Keywords: Coastal seawater quality, environmental monitoring, environmental parameter, South of Vietnam. 